\title{
Gardenia volkensii K. Schum. (Rubiaceae): Review of Medicinal uses, Phytochemistry and Biological Activities
}

\author{
Alfred Maroyi
}

\author{
Department of Botany, University of Fort Hare, Private Bag X1314, Alice 5700, South Africa
}

\begin{abstract}
Gardenia volkensii K. Schum. is a shrub or small tree widely used as traditional medicine throughout its distributional range in tropical Africa. This study is aimed at providing a critical review of the medicinal uses, phytochemistry and biological activities of G. volkensii. Documented information on the medicinal uses, phytochemistry and biological activities of G. volkensii was collected from several online sources, which included Scopus, Google Scholar, PubMed and Science Direct. Additional information was gathered from pre-electronic sources such as book chapters, books, journal articles and scientific publications sourced from the university library. The articles published between 1972 and 2020 were used in this study. This study showed that the species is widely used as emetic and protective charm, and as traditional medicine for infertility, sore eyes, sexually transmitted infections, headache, gastrointestinal infections, earache, convulsions, epilepsy and respiratory infections. Phytochemical compounds identified from the species include aldehydes, benzenoids, cinnamates, coumarins, essential oils, fatty acids, flavonoids, iridoids, phenolics, phytosterols and triterpenoids. Pharmacological research revealed that $G$. volkensii extracts and compounds isolated from the species have antibacterial, antifungal, antioxidant, mutagenic and antimutagenic and cytotoxicity activities. Future research on G. volkensii should focus on detailed phytochemical evaluations including toxicological, in vivo and clinical studies to corroborate the traditional medical applications of the species.
\end{abstract}

Keywords: Gardenia volkensii, ethnopharmacology, herbal medicine, indigenous pharmacopeia, Rubiaceae.

\section{INTRODUCTION}

Gardenia volkensii K. Schum. is a shrub or small tree belonging to Rubiaceae family, commonly known as coffee family. The genus Gardenia J. Ellis comprises of approximately 140 species of shrubs and trees found in tropical and warm temperate regions of Africa, Madagascar, East and Southeast Asia, western Pacific and Hawaiian islands [1,2]. The genus name is in the honour of Alexander Garden (1730-1791), a Scottish physician, botanist and zoologist who lived in Charleston, South Carolina and was a correspondent of Carl Linnaeus [3]. The species name "volkensii" is in the honour of Georg Ludwig August Volkens (18551917), a German botanist and plant collector on Mount Kilimanjaro in Tanzania from 1892 to 1894 [4]. The synonyms associated with the name $G$. volkensii include G. somalensis Fiori ex Chiov., G. spatulifolia Stapf \& Hutch., G. saundersiae N.E.Br., G. volkensii K. Schum. var. somalensis (Fiori ex Chiov.) Cufod. [5-7]. Three infraspecific taxa of $G$. volkensii are recognized and these include G. volkensii subsp. spatulifolia (Stapf \& Hutch.) Verdc. (recorded in southern Africa), a widespread $G$. volkensii subsp. volkensii recorded in eastern to central and southern Africa and G. volkensii subsp. volkensii var. saundersiae (N.E.Br.) Verdc. confined to southern Mozambique and KwaZulu-Natal

${ }^{*}$ Address correspondence to this author at the Department of Botany, University of Fort Hare, Private Bag X1314, Alice 5700, South Africa;

Tel/Fax: 0027719600326; E-mail: amaroyi@ufh.ac.za province in South Africa [5-7]. The English common names of $G$. volkensii include bushveld gardenia, common gardenia, sandveld gardenia, savanna gardenia, Transvaal gardenia, wild gardenia and woodland gardenia. In ethnobotanical literature, the infraspecific taxa of $G$. volkensii are rarely mentioned, therefore, in this study $G$. volkensii sensu lato is used throughout the manuscript.

Gardenia volkensii is a shrub or small sturdy tree with short, rigid branches and often multi-stemmed with dense crown, growing to a height of eight metres [8]. The bark is pale grey to reddish-brown in colour, smooth or slightly rough, flaking in thicker and older trees. The leaves of $G$. volkensii are usually whorled, or opposite, clustered at the ends of short lateral twigs, obovate in shape, hairless, and rarely with rough hairs above and below. The flowers are axillary, solitary, large and showy, white in colour and fading to cream with age. The fruits are oval to roundish in shape, grey in colour with longitudinal ribs, and have a rich winey smell when ripe. Gardenia volkensii has been recorded in Angola, Botswana, Eswatini, Ethiopia, Kenya, Malawi, Mozambique, Namibia, Tanzania, Uganda, Somalia, South Africa, Zambia and Zimbabwe [9-19]. Gardenia volkensii has been recorded in sandy, clay and rocky well-drained soils, edges of floodplains, coastal and lakeside areas, open woodlands, bushlands, riverine woodlands and coastal thickets at altitudes ranging from sea level to $1750 \mathrm{~m}$ above sea level [20]. Gardenia volkensii is widely planted as an 
ornamental tree and garden plant throughout the tropics [20]. The leaves of $G$. volkensii are browsed by game and livestock [3,21-24] while fruits are eaten by humans in Ethiopia [25,26] and Mozambique [27]. The roots of $G$. volkensii are sold as traditional medicines in informal herbal medicine markets of Gauteng and KwaZulu-Natal provinces in South Africa $[28,29]$. It is, therefore, within this context that the current study was undertaken aimed at documenting the pharmacological properties, phytochemistry and medicinal uses of $G$. volkensii.

\section{Medicinal uses}

The medicinal uses of $G$. volkensii have been recorded in Angola, Botswana, Eswatini, Ethiopia, Kenya, Malawi, Mozambique, Namibia, South Africa, Zambia and Zimbabwe, representing $71.4 \%$ of the countries where the species is indigenous. Major medicinal applications of $G$. volkensii that have been recorded in two countries and supported by at least three literature records, including the use of the species as emetic and protective charm, and as traditional

Table 1: Medicinal uses of Gardenia volkensii

\begin{tabular}{|c|c|c|c|}
\hline Medicinal use & Part used & Country & Reference \\
\hline Analgesic & Root infusion taken orally & Eswatini & [21] \\
\hline Anthelmintic & Fruit and root infusion taken orally & Eswatini and South Africa & {$[21,30]$} \\
\hline Antivenom & $\begin{array}{l}\text { Leaves mixed with those of Euclea } \\
\text { divinorum Hiern and Plectranthus } \\
\text { barbatus Andrews, and applied topically }\end{array}$ & Kenya & [35] \\
\hline Breast, skin and uterine cancer & Bark infusion taken orally & Kenya & [36] \\
\hline Convulsions and epilepsy & $\begin{array}{c}\text { Bark and root decoction or infusion } \\
\text { taken orally }\end{array}$ & $\begin{array}{l}\text { Botswana, Eswatini, Kenya, } \\
\text { South Africa and Zimbabwe }\end{array}$ & {$[24,32,37-40]$} \\
\hline Cosmetic & Flower infusion applied topically & South Africa & [41] \\
\hline Diabetes mellitus & Fruit infusion taken orally & Eswatini & [40] \\
\hline Earache & $\begin{array}{l}\text { Fruit decoction or infusion applied } \\
\text { topically }\end{array}$ & $\begin{array}{l}\text { Eswatini, Kenya, South Africa } \\
\text { and Zimbabwe }\end{array}$ & {$[24,30,37,39,40,42,43]$} \\
\hline Emetic & $\begin{array}{l}\text { Fruit and root decoction or infusion } \\
\text { taken orally }\end{array}$ & $\begin{array}{l}\text { Botswana, Eswatini, Kenya } \\
\text { and South Africa }\end{array}$ & {$[3,21,22,31,39,42-47]$} \\
\hline Erectile dysfunction & Leaf infusion taken orally & Angola and Zambia & {$[33,34]$} \\
\hline $\begin{array}{c}\text { Gastro-intestinal problems } \\
\text { (diarrhoea, dysentery and } \\
\text { stomach ache) }\end{array}$ & $\begin{array}{l}\text { Fruit and leaf decoction of infusion } \\
\text { taken orally }\end{array}$ & $\begin{array}{l}\text { Eswatini, Mozambique and } \\
\text { Namibia }\end{array}$ & {$[27,40,48-50]$} \\
\hline Headache & $\begin{array}{c}\text { Fruit, leaf and root decoction or infusion } \\
\text { taken orally }\end{array}$ & Eswatini, Kenya and Zimbabwe & {$[24,30,37,39,40,42,43]$} \\
\hline Infertility & Root and root bark infusion taken orally & Kenya and Zimbabwe & {$[37,39,51]$} \\
\hline Madness & Root decoction taken orally & Malawi & {$[37,39]$} \\
\hline Malaria & Fruit infusion taken orally & Kenya & {$[31,43]$} \\
\hline Menstrual problems & Root decoction taken orally & Zimbabwe & {$[37,39]$} \\
\hline $\begin{array}{l}\text { Protective charm (evil spirits, } \\
\text { lightning and witchcraft) }\end{array}$ & Leaves, roots and twigs & $\begin{array}{l}\text { Botswana, Eswatini, Kenya, } \\
\text { Mozambique, South Africa and } \\
\text { Zimbabwe }\end{array}$ & $\begin{array}{c}{[4,21,22,27,30,37,39,51,5} \\
2]\end{array}$ \\
\hline Purgative & Bark and root infusion taken orally & Botswana and Kenya & {$[31,32]$} \\
\hline $\begin{array}{l}\text { Respiratory infections (asthma, } \\
\text { chest complaints, colds and } \\
\text { pneumonia, sore throat and } \\
\text { tuberculosis) }\end{array}$ & $\begin{array}{c}\text { Root and stem bark infusion taken } \\
\text { orally }\end{array}$ & $\begin{array}{l}\text { Botswana, Eswatini, Namibia } \\
\text { and South Africa and } \\
\text { Zimbabwe }\end{array}$ & {$[24,30,37,39,40,53-55]$} \\
\hline $\begin{array}{l}\text { Sexually transmitted infections } \\
\text { (gonorrhoea, syphilis and } \\
\text { venereal diseases) }\end{array}$ & $\begin{array}{c}\text { Bark, leaf and root decoction or infusion } \\
\text { taken orally }\end{array}$ & Botswana, Kenya and Zambia & {$[32,34,56,57]$} \\
\hline Sore eyes & Root infusion applied topically & Zimbabwe and South Africa & {$[24,37,39]$} \\
\hline Vomiting & $\begin{array}{l}\text { Fruit and root decoction or infusion } \\
\text { taken orally }\end{array}$ & $\begin{array}{l}\text { Eswatini, Ethiopia, Kenya and } \\
\text { South Africa }\end{array}$ & {$[20,30,40,48,58]$} \\
\hline Weaning of babies & Leaf and root infusion applied topically & South Africa & {$[39,59]$} \\
\hline
\end{tabular}




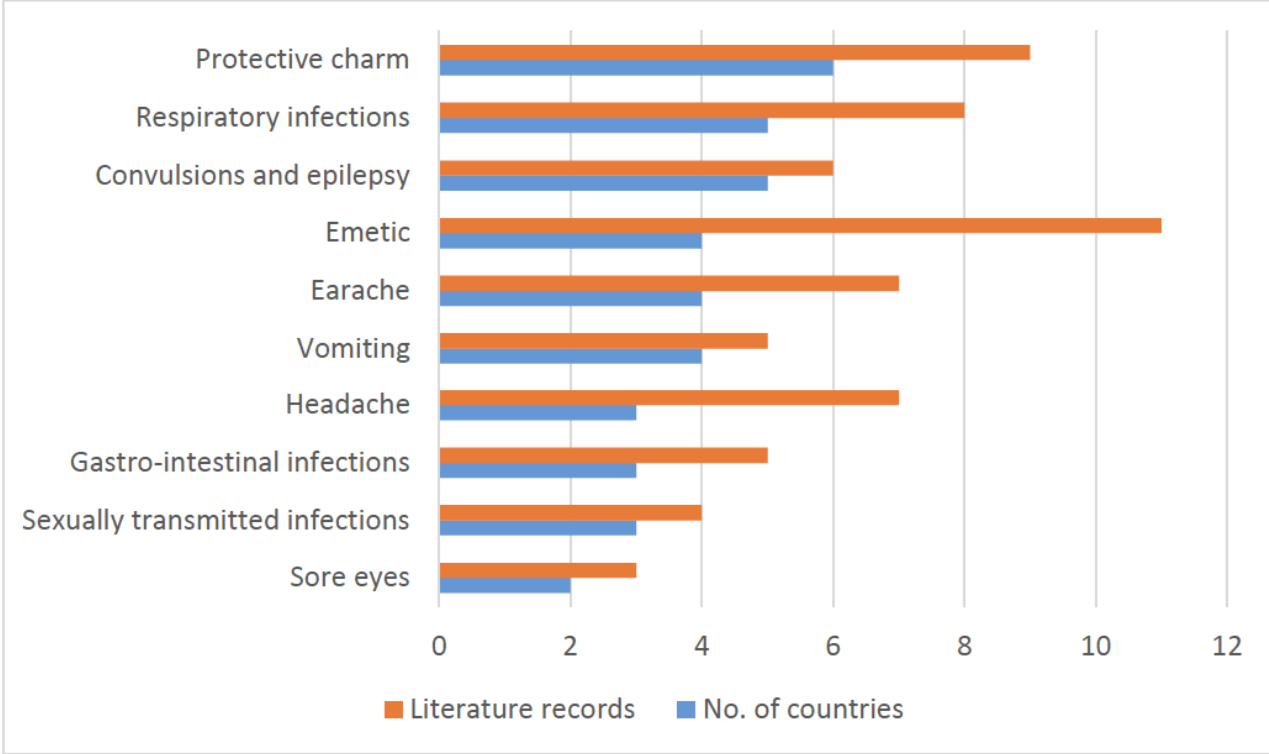

Figure 1: Medicinal applications of Gardenia volkensii derived from literature records.

medicine for infertility, sore eyes, sexually transmitted infections, headache, gastro-intestinal infections, earache, convulsions, epilepsy and respiratory infections (Table 1; Figure 1). Other medicinal applications of $G$. volkensii recorded in at least two countries include the use of the species as an anthelmintic [21,30] and purgative [31,32] and traditional medicine for erectile dysfunction $[33,34]$.

\section{Phytochemistry}

Peter [60], Juma and Majinda [61], Sibandze [40], Kinuthia et al. [42] and Suwannakud et al. [62] identified aldehydes, benzenoids, cinnamates, coumarins, essential oils, fatty acids, flavonoids, iridoids, phenolics, phytosterols and triterpenoids from the fruit pulp, fruits, leaves and seeds of $G$. volkensii (Table 2). Some of these phytochemical compounds may be responsible for the pharmacological properties exhibited by the species.

\section{Biological Activities of Gardenia volkensii}

Pharmacological research revealed that different extracts of $G$. volkensii and compounds isolated from the species have various biological activities such as antibacterial, antifungal, antioxidant, mutagenic and antimutagenic and cytotoxicity activities.

\section{Antibacterial Activities}

Mutta [63] evaluated the antibacterial activities of methanol extracts of $G$. volkensii roots against Staphylococcus aureus, Bacillus subtilis, Mycobacterium phlei, Streptococcus faecalis,
Escherichia coli, Salmonella typhimurium and Pseudomonas aeruginosa using the agar diffusion method with gentiamycin and 8-methoxypsoralen as positive controls. The extracts exhibited activities against the tested pathogens with the exception of Pseudomonas aeruginosa and Streptococcus faecalis with the inhibition zone ranging from $7.0 \mathrm{~mm}$ to 10.0 $\mathrm{mm}$ in comparison to $13.0 \mathrm{~mm}$ to $26.0 \mathrm{~mm}$ exhibited by the positive control [63]. Kinuthia et al. [43] evaluated the antibacterial activities of ethyl acetate, dichloromethane and hexane extracts of $G$. volkensii fruit pulp, leaves, seeds and stem bark, and the compound modified iridoid (GV2) against Escherichia coli, Salmonella typhimurium, Staphylococcus aureus and Bacillus subtilis using serial dilution assay with doxycycline $\AA$ as positive control. The extracts and compounds exhibited activities against Escherichia coli, Staphylococcus aureus and Bacillus subtilis with minimum inhibitory concentration (MIC) values ranging from $0.2 \mathrm{mg} / \mathrm{mL}$ to $>0.4 \mathrm{mg} / \mathrm{mL}$ [43]. Sibandze [40] evaluated the antibacterial activities of acetone extracts of $\mathrm{G}$. volkensii fruits and leaves against Escherichia coli, Staphylococcus epidermis, Staphylococcus aureus and Klebsiella pneumoniae using the microplate dilution method with ciprofloxacin $(0.01 \mathrm{mg} / \mathrm{ml})$ as positive control. The extracts exhibited activities against the tested pathogens with the MIC values ranging from $1.3 \mathrm{mg} / \mathrm{ml}$ to $12.0 \mathrm{mg} / \mathrm{ml}$ [40].

\section{Antifungal Activities}

Sibandze [40] evaluated the antifungal activities of acetone extracts of $G$. volkensii fruits and leaves against Candida albicans using the microplate dilution 
Table 2: Phytochemical Compounds Identified from Gardenia volkensii

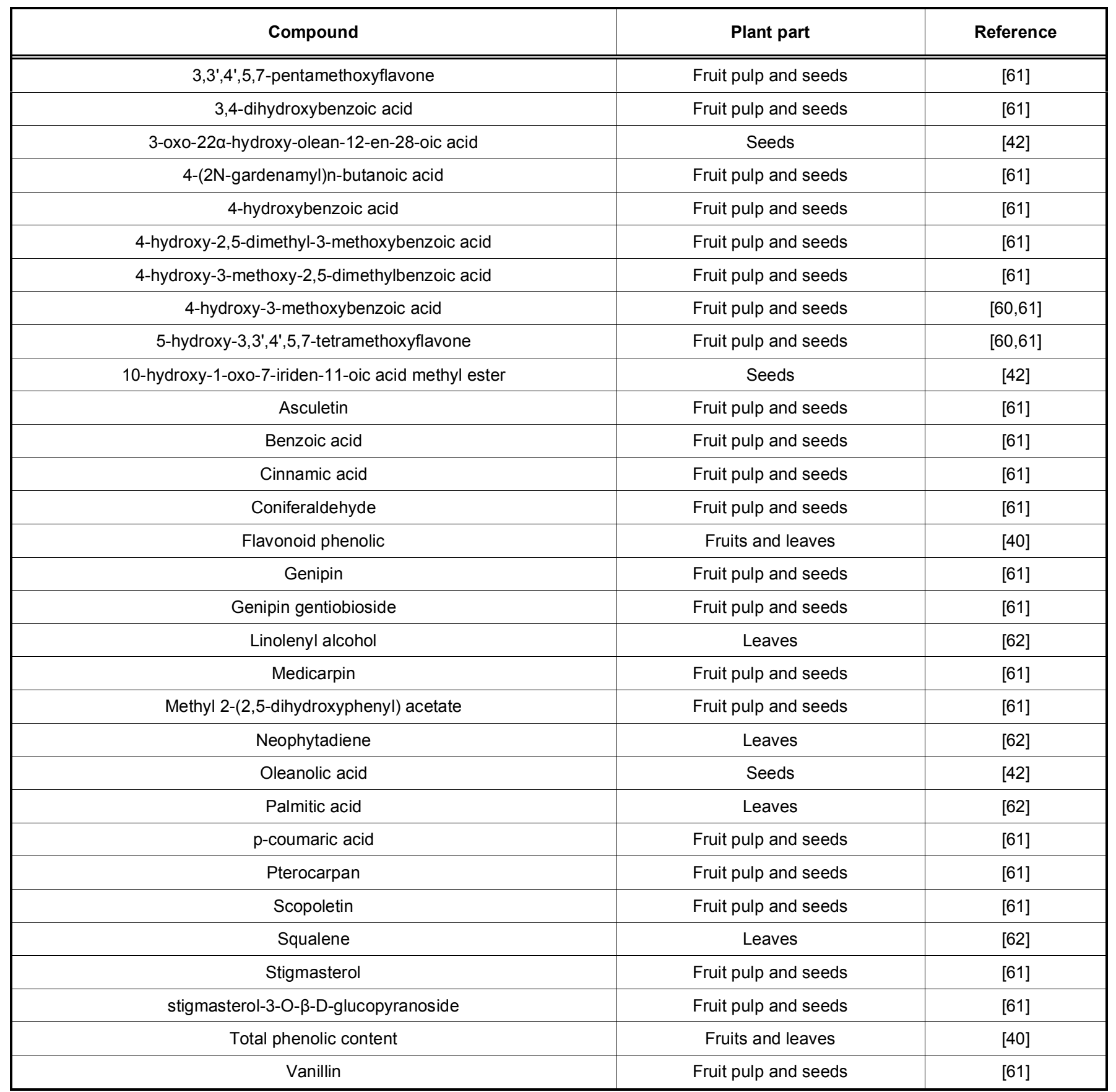

method with amphotericin B $(0.01 \mathrm{mg} / \mathrm{ml})$ as positive control. The leaf and fruit extracts exhibited activities against Candida albicans with the MIC values of 0.4 $\mathrm{mg} / \mathrm{ml}$ and $12.0 \mathrm{mg} / \mathrm{ml}$, respectively [40].

\section{Antioxidant Activities}

Juma and Majinda [61] evaluated the antioxidant activities of chloroform and methanol extracts of $G$. volkensii fruits and the compounds 3,4dihydroxybenzoic acid, 4-(2N-gardenamyl)n-butanoic acid, 4-hydroxybenzoic acid, 4-hydroxy-2,5-dimethyl-3- methoxybenzoic acid, asculetin, benzoic acid, cinnamic acid, genipin gentiobioside, medicarpin, p-coumaric acid, scopoletin, stigmasterol and stigmasterol-3-O- $\beta$ $D$-glucopyranoside, which were isolated from the fruit pulp and seeds of the species using 2,2-diphenyl-1picrylhydrazyl (DPPH) free radical scavenging assay with ascorbic acid $(0.05 \mu \mathrm{g})$ as positive control. The chloroform and methanol extracts, and the compounds genipin and medicarpin exhibited weak activities [61]. Sibandze [40] evaluated the antioxidant activities of acetone extracts of $G$. volkensii fruits and leaves using the DPPH free radical scavenging assay, metal 
chelating assay and inhibition of lipid peroxidation method with ascorbic acid and trolox as positive controls. The leaf extract exhibited the best activities demonstrated by half maximal inhibitory concentration $\left(\mathrm{IC}_{50}\right)$ value of $21.6 \mu \mathrm{g} / \mathrm{ml}$ in $\mathrm{DPPH},>100.0 \mu \mathrm{g} / \mathrm{ml}$ in metal chelation and $77.6 \%$ inhibition of lipid peroxidation at a concentration of $100.0 \mu \mathrm{g} / \mathrm{ml}$ [40].

\section{Mutagenic and Antimutagenic Activities}

Elgorashi et al. [64] evaluated the mutagenic activities of dichloromethane and $90 \%$ methanol extracts of $G$. volkensii bark, leaf and twigs using the Ames test performed on Salmonella typhimurium strain TA98, micronucleus test, comet assay and VITOTOX $®$ test. The extracts exhibited activities in micronucleus test and comet assay [64]. Similarly, Taylor et al. [65] evaluated the mutagenic activities of dichloromethane and $90 \%$ methanol extracts of the bark, leaves and twigs of $G$. volkensii using the Ames test performed on Salmonella typhimurium strains TA98 and TA100, micronucleus test, comet assay and VITOTOX® test. The extracts exhibited activities in comet assay [65]. Verschaeve et al. [66] evaluated the mutagenic and antimutagenic activities of dichloromethane extract of G. volkensii bark and twigs using the Ames test performed on Salmonella typhimurium strain TA98 and the micronucleus test. The extracts were genotoxic in the micronucleus test at a concentration of $100.0 \mu \mathrm{g} / \mathrm{ml}$ [66].

\section{Cytotoxicity Activities}

Sibandze [40] evaluated the cytotoxicity activities of acetone extracts of $G$. volkensii fruits and leaves against human kidney epithelial (Graham) cells using the 3-(4,5-dimethyl-2-thiazolyl)-2,5-diphenyl-2Htetrazolium bromide (MTT) assay. The fruit and leaf extracts exhibited activities with $\mathrm{IC}_{50}$ values of 21.3 $\mu \mathrm{g} / \mathrm{ml}$ and $89.5 \mu \mathrm{g} / \mathrm{ml}$, respectively [40].

\section{Toxicity Activities}

Juma and Majinda [61] evaluated the toxicity activities of chloroform and methanol extracts of $G$. volkensii fruits using the brine shrimp lethality test with potassium dichromate and bufadienolide scillaren $A$ as positive controls. The chloroform and methanol extracts exhibited activities with half maximal lethal dose $\left(L_{50}\right)$ value of $47.9 \mathrm{ppm}$ and $22.9 \mathrm{ppm}$, respectively, which were comparable to $L_{50}$ values of $25.4 \mathrm{ppm}$ and 190.9 ppm exhibited by potassium dichromate and bufadienolide scillaren $A$, respectively [61].

\section{CONCLUSION}

Palmer and Pitman [3] argued that the fruits of $G$. volkensii could be poisonous and, therefore, there is need for detailed clinical and toxicological evaluations of crude extracts and compounds isolated from the species. The widespread use of $G$. volkensii as food plant and source of traditional medicines throughout its distributional range in tropical Africa suggest that the species is not taken at toxic dosages. But use of $G$. volkensii as food and for the treatment of human diseases and ailments should be treated with caution, and rigorous toxicological and clinical studies of the bark, fruits, leaves, roots and seeds, and compounds isolated from the species are necessary.

\section{CONFLICT OF INTEREST}

No conflict of interest is associated with this work.

\section{REFERENCES}

[1] Wong KM, Low YW. A revision of Philippine Gardenia (Rubiaceae). Edinburgh J Bot 2011; 68: 11-32. https://doi.org/10.1017/S0960428610000272

[2] Govaerts R, et al. World Checklist of Rubiaceae. Richmond: Royal Botanic Gardens, Kew; 2011.

[3] Palmer E, Pitman N. Trees of southern Africa covering all known indigenous species in the Republic of South Africa, South-West Africa, Botswana, Lesotho and Swaziland. Cape Town: Balkema; 1972

[4] Schmidt E, Lotter M, McCleland W. Trees and shrubs of Mpumalanga and Kruger National Park. Johannesburg: Jacana Media; 2017.

[5] Verdcourt B. Notes on African Gardenia (Rubiaceae). Kew Bull 1979; 34(2): 345-360 https://doi.org/10.2307/4109996

[6] Bridson DM, Verdcourt B. Rubiaceae part 2. In Polhill RM (Ed.), Flora of Tropical East Africa. Rotterdam: Balkema; 1988, pp. 1-355.

[7] Bridson DM, Verdcourt B. Rubiaceae. In Pope GV (Ed.), Flora Zambesiaca 5 part 3. Richmond: Royal Botanic Gardens, Kew, 2003; pp. 671-674.

[8] Germishuizen G, Meyer NL. Plants of southern Africa: An annotated checklist. Pretoria: Strelitzia 14, National Botanical Institute; 2003

[9] Drummond RB. A list of trees, shrubs and woody climbers indigenous or naturalised in Rhodesia. Kirkia 1975; 10(2): 229-85.

[10] Da Silva MC, Izidine S, Amude AB. A preliminary checklist of the vascular plants of Mozambique. Pretoria: Southern African Botanical Diversity Network Report No. 30; 2004.

[11] Loffler L, Loffler P. Swaziland Tree Atlas: Including selected shrubs and climbers. Pretoria: Southern African Botanical Diversity Network Report No. 38; 2005.

[12] Phiri PSM. A checklist of Zambian vascular plants. Pretoria: Southern African Botanical Diversity Network Report No. 32; 2005.

[13] Setshogo MP. Preliminary checklist of the plants of Botswana. Pretoria: Southern African Botanical Diversity Network Report No. 37; 2005.

[14] Strugnell AM. A checklist of the spermatophytes of Mt. Mulanje, Malawi. Scripta Bot Belg 2006; 34: 1-199. 
[15] Van Wyk B, Van Wyk P. How to identify trees in southern Africa. Cape Town: Struik Nature; 2007.

[16] Figueiredo E, Smith GF. Plants of Angola. Pretoria: Strelitzia 22, South African National Biodiversity Institute; 2008.

[17] Mannheimer CA, Curtis BA. Le Roux and Müller's field guide to the trees and shrubs of Namibia. Windhoek: Macmillan Education Namibia; 2009.

[18] Thomas V, Grant R. Sappi tree spotting: KwaZulu-Natal and Eastern Cape. Johannesburg: Jacana Media (Pty) Ltd; 2013.

[19] Burrows JE, et al. Trees and shrubs of Mozambique. Cape Town: Publishing Print Matters (Pty); 2018.

[20] Dharani, N. Field guide to common trees and shrubs of East Africa. Cape Town: Struik Nature; 2019.

[21] Long C. Swaziland's flora: siSwati names and uses. Mbambane, Swaziland: Swaziland National Trust Commission; 2005. Available at: http://www.sntc.org.sz/ index.asp, accessed on 14 June 2020.

[22] Heath A, Heath R. Field guide to the plants of northern Botswana including the Okavango Delta: Useful in countries and geographical areas adjacent to northern Botswana in the Zambesi Basin. London: Kew Publishing, Royal Botanic Gardens, Kew; 2009.

[23] Botha J, Weiersbye IM. Ethnobotanic and forage uses of plants on mine properties in the Witwatersrand basin gold fields, South Africa. In Fourie A, Tibbett M, Wiertz J (Eds.). Mine closure. Perth: Australian Centre for Geomechanics; 2010, pp. 325-342.

[24] Venter F, Venter J-A. Making the most of indigenous trees. Pretoria: Briza Publications; 2015.

[25] Coppock DL. The Borana plateau of southern Ethiopia: Synthesis of pastoral research, development and change, 1980-1991. Addis Ababa: International Livestock Centre for Africa; 1994.

[26] Alemayehu G, Asfaw Z, Kelbessa E. Plant diversity and ethnobotany in Berehet District, North Shewa Zone of Amhara Region (Ethiopia) with emphasis on wild edible plants. J Med Plants Stud 2015; 3(6): 93-105.

[27] Ribeiro A, et al. Ethnobotanical survey in Canhane village, district of Massingir, Mozambique: medicinal plants and traditional knowledge. J Ethnobiol Ethnomed 2010; 6: 33. https://doi.org/10.1186/1746-4269-6-33

[28] Cunningham AB. African medicinal plants: Setting priorities at the interface between conservation and primary health care. Paris: People and Plants working paper 1, UNESCO, 1993.

[29] Williams VL, Balkwill K, Witkowski ETF. A lexicon of plants traded in the Witwatersrand umuthi shops, South Africa. Bothalia 2001; 31(1): 71-98. https://doi.org/10.4102/abc.v31i1.508

[30] Steyn H. Gardenia volkensii K. Schum. National Herbarium, Pretoria; 2010. http://pza.sanbi.org/gardenia-volkensii, accessed on 5 May 2020.

[31] Maundu P, et al. Ethnobotany of the Loita Maasai: Towards community management of the forest of the lost child experiences from the Loita Ethnobotany project. Paris: People and Plants Working Paper 8, UNESCO 2001.

[32] Motlhanka DMT, Nthoiwa GP. Ethnobotanical survey of medicinal plants of Tswapong North, in eastern Botswana: A case of plants from Mosweu and Seolwane villages. European J Med Plants 2013; 3(1): 10-24. https://doi.org/10.9734/EJMP/2013/1871

[33] Urso $V$, et al. Wild medicinal and food plants used by communities living in Mopane woodlands of southern Angola: Results of an ethnobotanical field investigation. J Ethnopharmacol 2016; 177: 126-139. https://doi.org/10.1016/j.jep.2015.11.041

[34] Chinsembu KC, Syakalima M, Semenya SS. Ethnomedicinal plants used by traditional healers in the management of
HIVIAIDS opportunistic diseases in Lusaka, Zambia. S Afr J Bot 2019; 122: 369-384.

https://doi.org/10.1016/j.sajb.2018.09.007

[35] Kigen G, et al. Ethnomedicinal plants traditionally used by the Keiyo community in Elgeyo Marakwet county, Kenya. J Biod Bioprospecting Develop 2014; 1(3): 11.

[36] Ochwang'i DO, et al. Medicinal plants used in treatment and management of cancer in Kakamega County, Kenya. J Ethnopharmacol 2014; 151: 1040-1055. https://doi.org/10.1016/j.jep.2013.11.051

[37] Gelfand $M$, et al. The traditional medical practitioner in Zimbabwe: His principles of practice and pharmacopoeia. Gweru: Mambo Press; 1985.

[38] Beentje HJ. Kenya trees, shrubs and lianas. Nairobi: National Museums of Kenya; 1994.

[39] Hutchings $A$, et al. Zulu medicinal plants: An inventory. Pietermaritzburg: University of Natal Press; 1996.

[40] Sibandze GF. Pharmacological properties of Swazi medicinal plants. MSc Dissertation. University of the Witwatersrand, Johannesburg; 2009.

[41] Setshego MV, et al. Natural resources used as folk cosmeceuticals among rural communities in Vhembe district municipality, Limpopo province, South Africa. BMC Compl Med Therapies 2020; 20: 81.

https://doi.org/10.1186/s12906-020-2869-x

[42] Kinuthia EW, et al. Constituents of Kenyan Gardenia volkensii. Nat Prod Comm 2012; 7(1): 13-14. https://doi.org/10.1177/1934578X1200700106

[43] Kinuthia EW, Mwangi EM, Cheplogoi PK. Screening for antimicrobial compounds in Gardenia volkensii fruits (Rubiaceae). Int J Sci Engin Res 2013; 4(4): 1253-1256.

[44] Bolten C. 1998. Healing knowledge and cultural practices in a modern Tswana village. MSc Dissertation. Massachusetts: Williams College; 1998.

[45] Palgrave MC. Keith Coates Palgrave trees of southern Africa. Cape Town: Struik Publishers; 2002.

[46] Kokwaro JO. Medicinal plants of East Africa. Nairobi: University of Nairobi Press; 2009.

[47] Kigen G, et al. Ethnopharmacological survey of the medicinal plants used in Tindiret, Nandi county, Kenya. Afr J Trad Compl Alt Med 2016; 13(3): 156-168. https://doi.org/10.4314/aitcam.v13i3.19

[48] Amusan OOG, et al. Some herbal remedies from Manzin region of Swaziland. J Ethnopharmacol 2002; 79: 109-112. https://doi.org/10.1016/S0378-8741(01)00381-6

[49] Conde $\mathrm{P}$, et al. The botanic mission to Mozambique (19421948): Contributions to the knowledge of the medicinal flora of Mozambique. História Ciências Saúde Manguinhos Rio de Janeiro 2014; 21: 2. https://doi.org/10.1590/S0104-59702014000200007

[50] Chinsembu KC, Hijarunguru A, Mbangu A. Ethnomedicinal plants used by traditional healers in the management of HIVIAIDS opportunistic diseases in Rundu, Kavango East region, Namibia. S Afr J Bot 2015; 100: 33-42. https://doi.org/10.1016/j.sajb.2015.05.009

[51] Pakia M, Cooke JA. The ethnobotany of the Midzichenda tribes of the coastal forest areas in Kenya: 2. Medicinal plant uses. S Afr J Bot 2003; 69(3): 382-395. https://doi.org/10.1016/S0254-6299(15)30321-5

[52] Van Wyk B, Van Wyk P. Field guide to trees of southern Africa. Cape Town: Struik Nature; 2013.

[53] Rodin RJ. The ethnobotany of the Khanyama Ovambos. Kansas: Allen Press Inc.; 1985. https://doi.org/10.5962/bhl.title.149934

[54] Hedberg I, Staugård F. Traditional medicine in Botswana: Traditional medicinal plants. Gaborone: Ipelegeng Publishers; 1989. 
[55] Mongalo NI, Makhafola TJ. Ethnobotanical knowledge of the lay people of Blouberg area (Pedi tribe), Limpopo province, South Africa. J Ethnobiol Ethnomed 2018; 14: 46. https://doi.org/10.1186/s13002-018-0245-4

[56] Danley K. Letters of the bush: A case study of traditional Setswana herbal medicine. Independent Study Project (ISP) Collection 270; 2006. Available from: https://digitalcollections.sit.edu/isp_collection/270, accessed on 25 May 2020 .

[57] Jeruto $\mathrm{P}$, et al. An inventory of medicinal plants used to treat gynaecological obstetric-urino-genital disorders in south Nandi Sub county in Kenya. J Nat Sci Res 2015; 5(18): 136152.

[58] Bekele-Tesemma A. Useful trees and shrubs for Ethiopia: Identification, propagation and management for 17 agroclimatic zones. Nairobi: Technical Manual No 6, RELMA; 2007.

[59] Mabogo DEN. The Ethnobotany of the VhaVenda. MSc Dissertation. Pretoria: University of Pretoria; 1990.

[60] Peter R. Phytochemical Investigation and biological activity studies of Gardenia volkensii. MSc Dissertation. Gaborone: University of Botswana; 2004.
[61] Juma BF, Majinda RRT. Constituents of Gardenia volkensii: Their brine shrimp lethality and DPPH radical scavenging properties. Nat Prod Res 2007; 21(2): 121-125. https://doi.org/10.1080/14786410600905907

[62] Suwannakud KS, et al. Chemical constituents of medicinal plants, Gardenia elata, G. gjellerupii, and G. volkensii. Int J Pharmacogn Phytochem Res 2017; 9(3); 293-296.

[63] Mutta DN. Antibiotic screening of plants used to treat infectious diseases in Kenya. MSc Dissertation. Vancouver: University of British Columbia 1995.

[64] Elgorashi EE, et al. The use of plants in traditional medicine: Potential genotoxic risks. S Afr J Bot 2002; 68: 408-410. https://doi.org/10.1016/S0254-6299(15)30409-9

[65] Taylor JLS, et al. Investigating the safety of plants used in south African traditional medicine, testing for genotoxicity in the micronucleus and alkaline Comet assays. Environ Mol Mutagen 2003; 42: 144-154. https://doi.org/10.1002/em.10184

[66] Verschaeve L, et al. Investigation of the antimutagenic effects of selected South African medicinal plant extracts. Toxicol Vitro 2004; 18: 29-35. https://doi.org/10.1016/S0887-2333(03)00131-0

\section{DOI: https://doi.org/10.29169/1927-5951.2020.10.05.1}

\section{(c) 2020 Alfred Maroyi; Licensee SET Publisher.}

This is an open access article licensed under the terms of the Creative Commons Attribution Non-Commercial License (http://creativecommons.org/licenses/by-nc/3.0/) which permits unrestricted, non-commercial use, distribution and reproduction in any medium, provided the work is properly cited 